\title{
Meziškolní mobilita žáků středních škol v České republice ${ }^{1}$
}

\author{
Dominik DvoŘák, Jan VyHNÁLek
}

\begin{abstract}
Abstrakt: Představujeme pilotni údaje o prestupech českých žáku mezi střednimi školami. Vycházime pri tom zadministrativnich mikrodat-zjarniho sběru údajư školni matriky v roce 2017. Analyzovali jsme 4533 př́padù přestupio. Agregovaná data ilustrujeme třemi př́pady řetèzených prestupư. Výsledky ukazuji, že 11,5\% prestupi směrovalo z maturitního na nematuritni obor, v opačném smèru jen 3,2\%. Ostatni prestupy nevedly ke zmènè typu studia. Počet zmèn školy bez zmèny obce trvalého pobytu výrazně regionálně kolísá. Meziškolni mobilita by mohla být dưležitým indikátorem upozorňujicím na rizikové žáky i školy. Metodologie analýzy administrativních dat má značný potenciál, ale současný systém sbèru a správy dat v českém školství zaostává za vyspělými zemèmi.
\end{abstract}

Klíčová slova: meziškolní mobilita, sekundární škola, administrativní data.

Vnější diferenciace vyššího sekundárního vzdělávání, podíly žáků v jednotlivých typech středních škol nebo počet oborů a míra jejich specializace $\mathrm{v}$ rámci odborného a učňovského školství jsou stálým předmětem diskusí mezi odborníky i širší veřejností. I v zemích, kde střední odborné školy mají dlouhou tradici a silné zastoupení, se klade důraz na prostupnost (permeabilitu) systému, kterou můžeme chápat jako vertikální prostupnost - např. ze středního (odborného) do postsekundárního vzdělávání, ale také jako horizontální prostupnost - tedy možnost přestupu mezi různými obory, mezi typy studia vedoucími $\mathrm{k}$ vyučení a $\mathrm{k}$ maturitě, popř. mezi všeobecným a odborným vzděláváním (CEDEFOP,
2012). Vysoký počet přestupů mezi školami (mobilita) však nemusí být jen pozitivním jevem, ale může také ukazovat na závažné problémy jedinců, škol nebo komunit. V každém př́padě bychom mobilitu měli zjištovat a lépe jí rozumět. Cílem tohoto článku je představit pilotní údaje o mobilitě ve středním školství a upozornit na potenciál (i limity) využití českých administrativních mikrodat pro studium nejen průměrných hodnot mobility, ale také pro analýzu na úrovni škol a žáků.

\section{VÝCHODISKA}

Meziškolní mobilita žáků je definována jako procesy související se situací, kdy dítě

\footnotetext{
${ }^{1}$ Tento výzkum byl podpořen z grantu GA ČR 18-19056S - Faktory ovlivňující kognitivní a nekognitivní výsledky žákủ ve středním odborném vzdělávání. Úloha pocitu akademické marnosti a kultury školy.
} 
„vstupuje do školy nebo ji opouští ve chvíli, která je odlišná od věku [a času], kdy normálně děti v daném typu školy začínají nebo končí studium, bez ohledu na to, zda je tento jev spojen se změnou bydliště" (Demie, Lewis \& Taplin, 2005; Dobson, 2008). Rumberger (2003) vymezuje meziškolní mobilitu jako změnu školy z jiného důvodu než postup na další úroveň vzdělávání. Používají se také další označení, např. transfery žáků, horizontální mobilita aj. (Vyhnálek, 2016). Meziškolní mobilita může být chápána jako víceméně neutrální jev (zejména pokud je vedlejším důsledkem mobility obyvatel) nebo dokonce jako pozitivní projev toho, že systém umožňuje rodičům a žákům uplatňovat právo na volbu školy (Dvořák \& Straková, 2016) a korigovat dřívější rozhodnutí ve věci volby studijního programu nebo konkrétní školní organizace. Současně však mohou být některé př́pady mobility indikátorem rizikových jevů na úrovni jednotlivce nebo projevem selhávání systému. Zvýšená meziškolní mobilita je totiž také významným korelátem, resp. prediktorem školní neúspěšnosti žáka (Rumberger, 2003). Dopad mobility na výsledky mobilních žáků zdůrazňuje i Hattie (2009, s. 81-82). Přestupy žáků mají ovšem vliv i na ostatní spolužáky ve trrídě, na učitele a na chod školy (Gibbons \& Telhaj, 2011; Rumberger, 2003; Mehana \& Reynolds, 2004).

Specifický obraz mobility pozorujeme v systémech, které uplatňují vnější diferenciaci žáků. Např́iklad Vlámové mluví o efektu vodopádu, kdy v diferencované sekundární škole s větší pravděpodobností žáci ze všeobecných tříd přecházejí („přepadávaji") do technických trríd a odtud pak dále do profesních (řemeslných) tříd. Pokud k přechodu dochází ve vyšších ročnících, tito žáci nezískají ukončené všeobecné vzdělání, ale ani nejsou v profesní př́pravě dost dlouho, aby si vytvořili manuální a technické dovednosti.

Změna školy má častý souběh s dalšími problémy dítěte nebo jeho rodiny. Specifickým fenoménem je řešení problémů ve škole opakovanými přechody ze školy na školu (Kerbow, 1996). Mobilitu lze chápat jako jeden z projevů postupného odcizování žáka škole v kontinuu, na jehož počátku jsou absence, potom mobilita, nakonec předčasný odchod ze vzdělávání čili drop-out (Gasper, DeLuca \& Estacion, 2012; Rumberger \& Larson, 1998). Rostoucí trend nedokončování vzdělání zejména u žáků učilišt je také u nás jedním z problémů středního odborného školství (Trhlíková, 2012), byt' současná míra je v evropském srovnání stále relativně příznivá (Hlad’o \& Šlapalová, 2018).

Existuje řada teoretických rámců, které se uplatňují při studiu a interpretaci příčin, průběhu a dopadů mobility - např. ekologicko-vývojové jako teorie školního vyvazování ${ }^{2}$ (disengagement; Finn, 1993), teorie životní dráhy (life course; Elder jr., 1996; Millová, 2009); teorie racionální volby (rational choice theory; Friedman \& Friedman, 1990), teorie sociálního kapitálu (Coleman, Bourdieu) aj. Náš výzkum má však pouze deskriptivní a explorativní

${ }^{2}$ Jako český ekvivalent se uvádí také ústup, odcizení, odpoutání. 
cíle, proto se teoretickým rámcům nebudeme blíže věnovat. Rozhodnutí o volbě školy nebo o její změně jsou ovlivňována souhrou pedagogických, sociálních a prostorových (geografických) faktorů (Bereményi \& Carrasco, 2018; Poupeau, François \& Elodie, 2007).

\subsection{Rozsah mobility a sociální a geografické rozdíly}

Je překvapivé, že o frekvenci přestupů žáků mezi školami v České republice chybějí byt́ i jen deskriptivní údaje. Ani pokud jde o zahraniční systémy, nenašli jsme př́liš podrobné informace, často chybí specifikace stupně vzdělávání. Podle Hattieho (2009, s. 82) se v USA každoročně stěhuje $20 \%$ žáků. Cordes et al. (2016) uvádějí, že v panelu newyorských žáků plných $98 \%$ změnilo v průběhu školní docházky (od předškolního do 12. ročníku) alespoň jednou školu, přičemž žáci z chudších čtvrtí New Yorku vykazují významně vyšší rezidenční mobilitu než jejich vrstevníci z bohatších čtvrtí. ${ }^{3}$ Také dle Welshe (2017) je meziškolní mobilita nejčastější u žáků $\mathrm{z}$ etnických menšin, nízkoprríjmových skupin a městských škol.

Jak naznačil předchozí odstavec, většina publikovaných výzkumů se vztahuje $\mathrm{k}$ anglofonním zemím, jejichž sekundární školství má z hlediska stratifikace odlišnou podobu než náš vzdělávací systém. $\mathrm{V}$ evropských kontinentálních zemích $s$ diferencovaným školstvím se mobili- tě věnuje pozornost např. $\mathrm{v}$ Lucembursku (Backes \& Hadjar, 2017). Jacobová \& Tiebenová (2007, 2009) zjistily pro Německo a Nizozemsko, že děti z vyšších sociálních vrstev využívají mobilitu pro zlepšení statusu - přestup „nahoru“, kdežto u dětí s horším zázemím je vyšší pravděpodobnost „sestupu“ do oboru/ školy s nižší prestiží.

\subsection{Výzkumné otázky}

Náš výzkum se, pokud jde o české střední školství, snaží alespoň částečně zaplnit existující mezeru: cílem je uvést základní četnosti přestupů ve středním školství a popsat jejich regionální variabilitu. V souvislosti s volbou střední školy je podle P. Hlad'a (Hlad'o, 2010a, 2010b; Hlad'o \& Drahoňovská, 2012) vhodnější mluvit spíše o volbě další vzdělávací dráhy než o volbě povolání, zajímají nás tedy přestupy mezi různými typy studijních oborů jako zásadní revize této dráhy. Proto hledáme odpovědi na následující výzkumné otázky: Kolik žáků přestupuje z maturitních oborů do oborů s výučním listem a naopak? Jak se mobilita liší v rámci České republiky regionálně? Jaká data jsou $\mathrm{k}$ dispozici pro zodpovězení těchto a podobných otázek?

\section{Metodologie:}

\section{ADMINISTRATIVNÍ DATA}

Náš výzkumný plán se podobá censu neboli totálnímu/úplnému výběru (Hendl \& Remr, 2017), tedy observační studii, při

${ }^{3}$ Článek neuvádí př̌snou operacionalizaci meziškolní mobility. 
níž jsou sbírána data od každého člena cílové populace. Zpracováváme data o všech žácích středních škol v ČR, kteří ve vymezeném období presestoupili z jedné školy do jiné. Specifikem našeho př́stupu však je, že nepořizujeme vlastní data, ale využíváme tzv. administrativní mikrodata. Jedná se o data rutinně vytvářená a reportovaná veřejnou nebo státní správou ${ }^{4} \mathrm{z}$ důvodů řízení a evidence v organizaci nebo v rezortu. Nejsou tedy primárně určena pro výzkumné ani statistické účely. Pokud existuje povinnost vedení př́ślušné evidence uložená zákonem, mohou být tato data prakticky úplná, což je situace, které se např. u výběrového šetření nedá dosáhnout (Srholec, 2016).

Statistiky školství založené na administrativních datech, včetně poměrně podrobných informací o odborném školství, jsou v České republice vytváreny dlouhodobě a jejich výstupy byly rovněž výzkumníky tradičně využívány. $U$ administrativních mikrodat se však nepracuje s agregovanými informacemi (průměry), ale pro výzkumné účely se využívají původní, popř. propojená data o každé jednotce - tedy žákovi (učiteli, škole...), která jsou anonymizovaná - odpovídají legislativě na ochranu dat (v níž jsou ustanovení o použití dat pro účely výzkumu a evaluace). To umožňuje - na rozdíl od běžně uvolňovaných dat jednak podrobnější tř́idění podle potřeb výzkumníka (první část následující kapitoly), ale také propojovaní dat na úrovni jedince (druhá část výsledků).

Census bývá v metodologických textech charakterizován jako „složitý, časově a finančně náročný" postup, jenž se proto obvykle nahrazuje výběrovým šetřením (Hendl, 2012, s. 56). Administrativní data naopak poskytují - a to i ve srovnání $s$ výběrovým šetřením - relativně levný, v principu rychlý, byt ne vždy snadný způsob získání dat o celé sledované populaci. Při využití administrativních dat nejsou zatěžováni respondenti (ředitelé, školy) novými dotazníky nebo jinými technikami sběru dat. Výzkum se však liší od censu nebo statistického šetření v tom, že neumožňuje výzkumníkovi kontrolu nad tím, jaké informace jsou sbírány. Podobá se tedy sekundární analýze dat.

Scharleová (2018) připomíná, že $v$ praxi se na cestě $k$ administrativním datům můžeme setkat $s$ řadou dalších překážek: chybějí jasné postupy uvolňování dat a jejich vlastníci se obávají negativní publicity, protože se může ukázat nízká kvalita dat státních orgánů nebo věcné problémy. Vlastníci nechtějí ztratit monopolní prrístup $\mathrm{k}$ datům (a potenciální moc či zisk z něj plynoucí). Politici navíc nemusí mít zájem na evidence based prrístupu - cítí se ohroženi, protože nevěří anonymizačním algoritmům, domnívají se, že výzkumníci mohou sledovat skrytou agendu, aj. I když náklady na přípravu datových souborů jsou obvykle velmi malé ve srovnání s novým sběrem dat, přesto anonymizace vyžaduje čas úředníků a stojí peníze. Proces získání administrativních dat může u komplikovaných souborů trvat až roky, data mezitím zastarávají.

${ }^{4}$ Např. ředitele školy lze považovat za orgán státní správy. 
Tab. 1. Př́klady administrativních dat dle OECD (zdroj: OECD, 2016)

\begin{tabular}{|l|l|l|}
\hline \multicolumn{2}{|l|}{ Kategorie dat } & Př́klady \\
\hline A & státní transakce & $\begin{array}{l}\text { daně, sociální pojištění, sociální dávky, cla a související hlášení } \\
\text { o mezinárodním pohybu zboží }\end{array}$ \\
\hline B & $\begin{array}{l}\text { státní rejstříky } \\
\text { a evidence }\end{array}$ & $\begin{array}{l}\text { matriky obyvatelstva, katastr nemovitostí, rejstř́ík trestů, volební } \\
\text { seznamy, zdravotnická dokumentace, evidence vedená školami }\end{array}$ \\
\hline C & $\begin{array}{l}\text { záznamy komerčních } \\
\text { subjektů }\end{array}$ & $\begin{array}{l}\text { zákaznické karty; účty zákazníků bank, komunikačních společností } \\
\text { apod.; kupní smlouvy }\end{array}$ \\
\hline D & $\begin{array}{l}\text { data o užívání } \\
\text { internetu }\end{array}$ & $\begin{array}{l}\text { termíny vyhledávané prostřednictvím služby Google; počty návštěvníků } \\
\text { stránek; stahování různých médií; aktivita na sociálních sítích; blogy }\end{array}$ \\
\hline E & $\begin{array}{l}\text { tracking } \\
\text { data o poloze mobilních telefonů; GPS; záznamy z monitorování pro- } \\
\text { střednictvím videokamer; záznamy o pohybu vozidel (mýtné brány) }\end{array}$ \\
\hline F & $\begin{array}{l}\text { satelitní a letecké } \\
\text { snímkování }\end{array}$ & satelitní snímky, Google Earth \\
\hline
\end{tabular}

Problematika administrativních dat souvisí s hnutím za otevřená data jako součástí úsilí o open government. Otevřená data jsou data, která jsou dostupná každému, zdarma, dálkově a $\mathrm{v}$ strojově čitelném formátu, bez omezení použití. Panuje naděje, že široká dostupnost takovýchto dat (v našem prrípadě o školství) posílí transparentnost a efektivitu vzdělávací politiky a praxe, zlepší nabídku vzdělávání i spokojenost aktérů a kvalitu jejich života (Kubáñ, 2016).

\subsection{Význam registrů ve školství}

V zahraničních vzdělávacích systémech je kladen velký důraz na shromažd’ování a zpřístupňování podrobných administrativních dat pro účely monitorování, řízení a výzkumu školství. Například ve Velké Británii byla $\mathrm{v}$ průběhu devadesátých let minulého století vytvořena kompletní databáze žáků (pupil register) ve věku
5-16 let. Vybudování systému včetně unikátního identifikátoru žáků a dalších technických a administrativních opatření nebylo rychlé ani snadné. Nakonec však podle Oatese $(2017$, s. 33) lze celý projekt považovat za významný úspěch státní správy, díky němuž jsou $\mathrm{k}$ dispozici velmi obsáhlá data o žácích a školách, která jsou nyní využívána mj. pro inspekci a hodnocení škol, správné nastavení kritérií hodnocení externích zkoušek a v neposlední řadě také pro výzkumné účely.

Česko a další středoevropské země mají dlouhou tradici pečlivého sběru administrativních dat sahající do dob rakouské monarchie a komunistické vlády se svou orientací na centrální plánování a příslušné výkaznictví ji dále posilovaly. Přesto se $\mathrm{v}$ české pedagogice administrativní mikrodata zatím používají pro výzkum, evaluaci a na dokladech založenou vzdělávací politiku málo. $\mathrm{K}$ př́činám může patřit to, že klíčové prúi práci s tímto typem mikrodat 
je propojování dat $\mathrm{z}$ různých administrativních databází, které často obsahují citlivé informace. Př́stup $k$ datům a zejména propojování jsou tak omezeny legislativními bariérami (GDPR), ale podle našich dosavadních zkušeností také nekompatibilitou informačních systémů různých rezortů a úřadů nebo nedůvěrou mezi nimi navzájem. ${ }^{5}$

Významnějšího pokroku bylo dosaženo v Mad’arsku, kde byl přijat nový zákon, který má usnadnit prístup $\mathrm{k}$ administrativním datům (Scharle, 2018). Od roku 2011 se např. pravidelně sleduje kariéra absolventů různých univerzit a oborů na základě propojení dat ze čtyř rezortů (školství, daňová správa, zdravotní registr a nezaměstnanost). Administrativně propojená data rovněž byla využita $\mathrm{k}$ výzkumu vzdělanostních rozdílů mezi Romy a neromskou populací (Kertesi \& Kézdi, 2011).

\subsection{Popis dat}

Českou školní matriku lze považovat za kvalitní zdroj informací, nebot' na tato data dosud je navázáno financování škol (per capita), a je tedy zájmem aktérů, aby data byla přesná a aktuální. Zároveň však $\mathrm{z}$ důvodů ochrany dat má k odpovídajícím databázím přímý prístup jen velmi omezený okruh osob. Malá dostupnost mikrodat ve srovnání s rozvinutými západními zeměmi a absence některých důležitých údajů (např. o sociálním původu žáků) v datech nepochybně znevýhodňují český pedagogický výzkum, ale především snižují efektivitu rrízení školského systému. ${ }^{6}$

MŠMT ČR na základě zákonného zmocnění provádí ročně dva sběry matrikových dat. $\mathrm{V}$ tomto článku vycházíme $\mathrm{z}$,jarních dat" pokrývajících období od 1. 9. 2016 do 31. 3. 2017, která nám laskavě po anonymizaci poskytl odbor školské statistiky, analýz a informační strategie MŠMT ČR. Vzhledem k výše popsaným problémům si vstř́cnosti pracovníků MŠMT ČR velice váźíme. Z celkového souboru dat o všech žácích českých středních škol (přibližně 424 tisíc) jsme obdrželi záznamy, které se vztahovaly ke změně školy přestupem.

Klíčový je způsob anonymizace dat. Každému žákovi je přidělen bezvýznamový identifikátor, ${ }^{7}$ který je pro všechny informace o žákovi $\mathrm{v}$ daném sběru totožny. ${ }^{8}$ Tím můžeme zachytit i opakované přestupy téhož jedince ve sledovaném období. $V$ dalších sběrech je však

\footnotetext{
${ }_{5}^{5}$ Využívání dat z administrativních zdrojů podporují evropské orgány (např. Nařízení Evropského parlamentu a Rady 2015/759 ze dne 29. dubna 2015), př́stup k administrativním datům je však usnadněn pro ČSÚ a další pracoviště státní statistické služby, nikoli pro výzkumníky.

${ }^{6}$ Excesy, jako např́iklad v listopadu 2018 zjištěná chyba zabezpečení dat České školní inspekce, by podle našeho názoru neměly být důvodem k opuštění myšlenky plošného sběru dat, ale spíše výzvou k budování kapacit tak, aby $\mathrm{k}$ podobným situacím docházelo co nejméně.

${ }^{7}$ Přesněji řečeno, propojit lze pouze data, která nejsou považována za citlivá. Například informace o zdravotním znevýhodnění propojit $s$ konkrétním žákem ani v originálním souboru ministerstva nelze.

${ }^{8}$ Pro zajímavost, nap̌r. 24ae2fd6d7b4116f9f17b2808cb121f8 je identifikátor, kterým byl v anonymizovaném souboru označen „Matěj“ popisovaný v kapitole 3.2.
} 
žákovi již přidělena odlišná hodnota identifikátoru, takže není možné propojit data o jedinci $z$ více sběrů (tedy např. za více školních roků) nebo data $\mathrm{z}$ jiných registrů.

Soubor, který jsme obdrželi, obsahoval 9192 datových vět typu „zahájení studia ve škole“ a 7536 vět o „ukončení studia“. V této studii reportujeme dosud zpracované výsledky o nejjednodušších případech, kdy žákovi $\mathrm{v}$ souboru odpovídaly právě dvě datové věty a žák skutečně přestoupil na jinou školu. Neanalyzovali jsme zatím př́pady, kdy změna proběhla jen $\mathrm{v}$ rámci jedné školy nebo měla jen administrativní charakter (např. změna jména) - šlo jednak o osamocené záznamy (2441 př́padů) a dále 510 párů záznamů v souborech dohromady (255 žáků). Dále jsme nezpracovali prrípady, kdy o žákovi byly více než dvě datové věty - jednalo se celkem o 1288 jedinečných žáků; tyto prŕípady budou vyžadovat většinou poměrně náročnou ruční analýzu a interpretaci (viz tab. 2 a tř̌i případy uvedené v druhé části této kapitoly). Výsledky ve zbytku podkapitoly tedy vycházejí z analýzy dat o $n=4533$ žácích, kteří ve sledovaném období jednou změnili školu.

Získaná data jsme analyzovali jednak $s$ využitím informace o geografické poloze místa trvalého pobytu (obec a kraj), jednak jsou srovnávána data $\mathrm{v}$ různých typech škol a studijních oborů. Doplnili jsme je o vysvětlující údaje z běžně dostupného rejstř́íku škol, nespojovali jsme je však s žádnými dalšími rejstř́íky na úrovni žáka (viz diskuse).
Tab. 2. Př́ípady, kdy o jednom žákovi bylo více datových vět

\begin{tabular}{|c|c|}
\hline Počet vět o žákovi & Počet žáků \\
\hline 3 & 819 \\
\hline 4 & 207 \\
\hline 5 & 189 \\
\hline 6 & 49 \\
\hline 7 & 11 \\
\hline 8 & 9 \\
\hline 9 & 3 \\
\hline 10 & 1 \\
\hline Celkem & 1288 \\
\hline
\end{tabular}

\section{VÝSLEDKY}

Uvedeme nejdříve kvantitativní výsledky zpracování souboru dat o jednodušších prrípadech přstupů a pak pro ilustraci představíme tři složitější případy řetězených přestupů.

\subsection{Agregované výsledky}

U meziškolní mobility jsme očekávali tř̌i možné mechanismy: rezidenční mobilitu (stěhování rodiny), řešení problémů žáka (studijních, kázeňských, sociálních) prestupem nebo snahu najít lepši školu (strategická mobilita). $\mathrm{V}$ našich datech umíme rozlišit jen to, kdy je změna školy souběžná se změnou obce, kterou žák uvádí jako místo trvalého pobytu, a kdy nikoli. Tabulka 3 uvádí podíl př́ípadù, kdy souběžně se změnou školy došlo ke změně obce trvalého pobytu žáka. Současně uvádíme poměr přestupů mezi maturitními (ISCED 3A nebo ISCED 3B) a nematuritními obory (ISCED 3C). Data 
Tab. 3. Mobilita podle př́tomnosti změny obce trvalého pobytu a přestupu mezi maturitními a nematuritními obory

\begin{tabular}{|l|c|c|c|c|c|}
\hline \multirow{2}{*}{$\begin{array}{l}\text { Změna obce } \\
\text { pobytu }\end{array}$} & \multicolumn{5}{|c|}{ Výchozí a cílová kategorie ISCED 3 (údaje v \%) } \\
\cline { 2 - 6 } & $\mathbf{A B} \rightarrow \mathbf{A B}$ & $\mathbf{A B} \rightarrow \mathbf{C}$ & $\mathbf{C} \rightarrow \mathbf{A B}$ & $\mathbf{C} \rightarrow \mathbf{C}$ & Celkem \\
\hline ne & 58,1 & 12,1 & 3,3 & 26,5 & 76 \\
\hline ano & 56,7 & 9,6 & 3,2 & 30,4 & 24 \\
\hline Celkem & $\mathbf{5 7 , 8}$ & $\mathbf{1 1 , 5}$ & $\mathbf{3 , 2}$ & $\mathbf{2 7 , 4}$ & $\mathbf{1 0 0 , 0}$ \\
\hline
\end{tabular}

Poznámka: AB znamená maturitni obory (ISCED 3A, ISCED 3B), C znamená obory nematuritní, zakončené prevážně výučním listem (ISCED 3C).

Tab. 4. Přestupy mezi maturitními a nematuritními obory podle ročníku

\begin{tabular}{|l|c|c|c|c|}
\hline & \multicolumn{4}{|c|}{ Výchozí a cílová kategorie ISCED (\%) } \\
\hline Ročník & $\mathbf{A B} \rightarrow \mathbf{A B}$ & $\mathbf{A B} \rightarrow \mathbf{C}$ & $\mathbf{C} \rightarrow \mathbf{A B}$ & $\mathbf{C} \rightarrow \mathbf{C}$ \\
\hline 1 & 61,33 & 53,76 & 76,87 & 66,96 \\
\hline 2 & 21,94 & 26,78 & 21,09 & 25,48 \\
\hline 3 & 12,90 & 13,49 & 2,04 & 7,56 \\
\hline 4 & 3,83 & 5,97 & & \\
\hline Celkem & $\mathbf{1 0 0 , 0 0}$ & $\mathbf{1 0 0 , 0 0}$ & $\mathbf{1 0 0 , 0 0}$ & $\mathbf{1 0 0 , 0 0}$ \\
\hline
\end{tabular}

Poznámka: AB znamená maturitní obory (ISCED 3A, ISCED 3B), C znamená obory nematuritní, zakončené prevážně výučním listem (ISCED 3C).

naznačují, že i v českém školství nastává efekt vodopádu. Žáci výrazně častěji přestupují z maturitních oborů do kratších oborů zakončených výučním listem než naopak. Přesto zdaleka nejvíce přestupů, které jsme zaznamenali, probíhá $\mathrm{v}$ rámci stejného typu středoškolského studia ( $\mathrm{tj}$. bud' maturitního, nebo nematuritního).

Tabulka 4 uvádí, jaký je poměr přestupů mezi školami z hlediska ročníku, z nějž žák odchází, ve vztahu $\mathrm{k}$ tomu, zda dochází ke změně typu studia. Přestupy z učňovských do maturitních oborů se odehrávají většinou v prvním ročníku (tři čtvrtiny těchto přestupů), později budou logicky obtížnější. Ale i ostatní typy přestupů $\mathrm{v}$ našich datech nastaly hlavně $\mathrm{v}$ prvním ročníku. ${ }^{9}$ Obrázek 1 dokumentuje regionální rozdíly ve frekvenci přestupů mezi školami podle krajů České republiky (vztaženo na celkový počet žáků středních škol $\mathrm{v}$ daném kraji). $Z$ důvodů uvedených výše netestujeme významnost rozdílù, ale zaznamenáváme, že zejména non-rezidenční změny školy jsou nápadně zvýšené v severozápadních Čechách.

${ }^{9}$ Data by již nyní umožnila analýzu v podrobnějším časovém členění - např. po měsících. 


\subsection{Analýza na úrovni jednotlivých žáků}

Pro ilustraci možností práce $s$ mikrodaty jsme zpracovali tři př́ípady žáků (dva chlapce a jednu dívku), ke kterým se v primárním souboru vztahovalo vždy devět datových vět. Představují tak opačný typ MM než relativně jednoduché prŕípady přestupů, které byly zpracovány $\mathrm{v}$ předchozí ćásti článku. Žáky jsme označili jako Matěje, který pochází ze střední Moravy; Čendu ze středních Čech a Věrku z Českomoravské vrchoviny. Primární data obsahují také obec jejich trvalého pobytu, tu jsme se však rozhodli neuvádět, protože by teoreticky mohla vést $\mathrm{k}$ identifikaci žáků, stejně jako jednoznačná identifikace škol, kterými prošli.

Ukázalo se, že všichni žáci ve sledovaném období postupně navštěvovali čtyři stř̌ední školy, avšak žádný z nich nezměnil trvalý pobyt. $\mathrm{V}$ tom smyslu odpovídají našemu zjištění o převažujícím typu změn (nevíme ovšem nic o jejich skutečném místě pobytu a jeho případných změnách). Studovali v běžných, nikoli speciálních třídách. Všichni byli ve sledovaném období v prvním ročníku střední školy v denní formě studia, všichni byli občané České republiky. Jako první cizí jazyk studovali angličtinu. Matějovi bylo 1. záŕí 2016 patnáct let, Čendovi a Věrce o rok víc. Oba chlapci

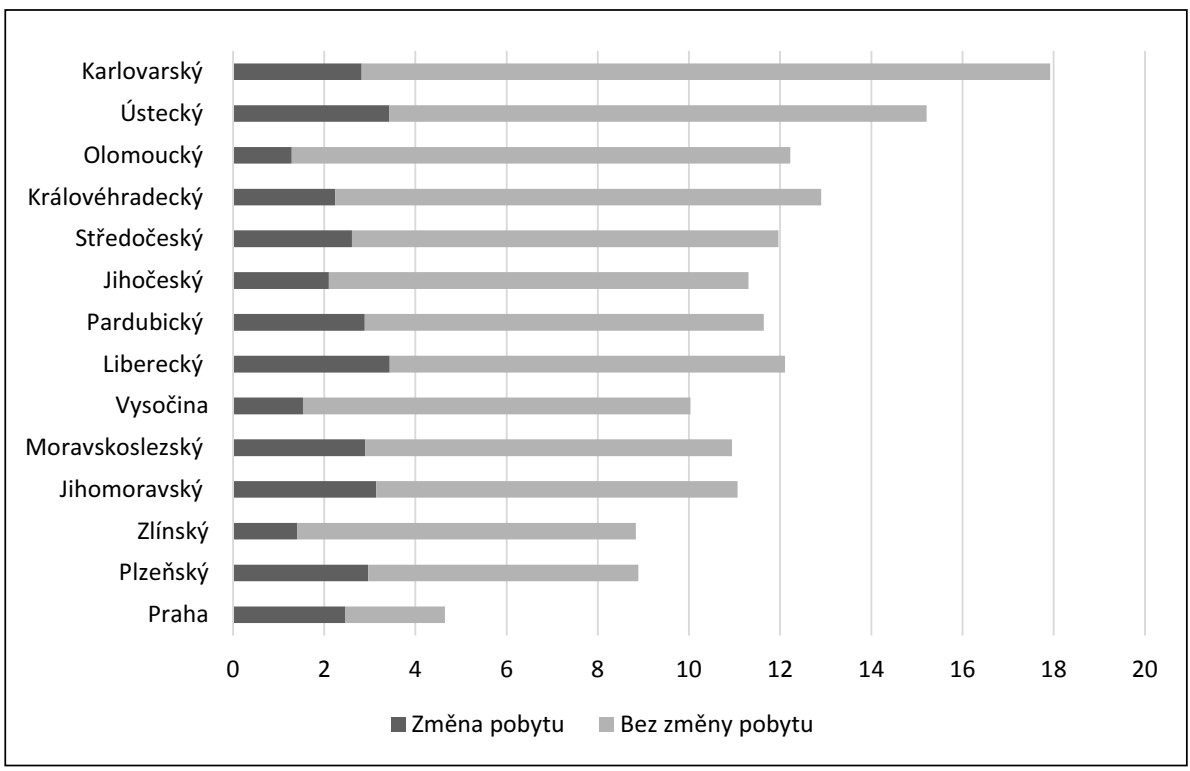

Obr. 1. Regionální rozdíly v mobilitě (počet přestupů na tisíc žáků středních škol v daném kraji) $\mathrm{v}$ rozlišení na mobilitu spojenou se změnou obce trvalého pobytu a bez ní 
na střední školu nastoupili po ukončení 9. ročníku základní školy, Věrka z 8. ročníku (pravděpodobně jednou opakovala ročník, nebot' rovněž již splnila devítiletou povinnou docházku). Průběh jejich vzdělávací dráhy ukazuje tabulka 5 .

Matěj v průběhu prvních zhruba šesti týdnů školního roku vystřídal čtyři školy, přičemž se zdá, že na poslední z nich zakotvil. Silniční vzdálenost první školy od obce jeho trvalého pobytu byla $120 \mathrm{~km}$, u druhé a třetí školy to bylo pod $20 \mathrm{~km}$ a u poslední školy asi $10 \mathrm{~km}$. Studované obory se značně liší - obchodní akademie, pak zemědělec-farmář, znovu obchodní akademie, pak obráběč kovů. Začínal tedy čtyřletý obor s maturitou, ale poslední známý obor studia je tř́letý $s$ výučním listem. $Z$ výše uvedených dat plyne, že pravděpodobnost, že by se později ještě vrátil na maturitní obor, je spíše menší. V prýípadě Čendy jde o případ návratu do školy, v níž už žák jednou studoval. Čenda také podstoupil méně obvyklý přestup z učebního na maturitní obor, ale nesetrval tam. Trvalý pobyt měl žák ve středočeském městě vzdáleném asi $50 \mathrm{~km}$ od Prahy, maturitní obor však studoval v obci, kam cesta $\mathrm{z}$ obce trvalého pobytu veřejnou dopravou trvá déle než tři hodiny.

Konečně Věrka zastupuje případ, který by nás z hlediska dalš́ího výzkumu zvláště zajímal, protože ve sledovaném období zcela zanechala vzdělávání. Ze školy, na kterou byla pravděpodobně přijata po základní škole (přesně ji neznáme, nebot škola má více pracovišt'), ihned na začátku školního roku přestoupila na stejný obor kuchař-číšník na jiné škole (vzdálené od původní školy $60 \mathrm{~km}$ ). Většinu prvního pololetí však strávila ve škole při výchovném ústavu, kam jsou indikovány děti se závažnými poruchami chování. Na základě dostupných informací nelze vyloučit, že již v době přijetí ke studiu na předchozí, popř. i následující škole byla $\mathrm{v}$ ústavní péči. $V$ průběhu druhého pololetí se vrátila na první školu (o které víme, že spolupracuje s výchovným ústavem), avšak po zhruba měsíci došlo $k$ předčasnému odchodu ze vzdělávání. Věrka tak zastupuje př́ipady, kdy vyšší počet přestupů koreluje s problémy na straně žáka a zároveň předchází zanechání vzdělávání.

\section{DisKUSE}

Vzhledem k našim dvěma cílům - věcnému a metodologickému - rozdělíme analogicky i diskusi.

\subsection{Věcná zjištění}

Kumulace zachycených změn do prvního ročníku naznačuje, že při studiu přestupů jsme především svědky korekce původní volby školy, jak uvádějí Hlad’o a Šlapalová (2018). Tomu odpovídá i skutečnost, že př́ípady změny školy doložitelně spojené $s$ rezidenční mobilitou tvoří jen $24 \%$ z celkového počtu přestupů. Celé tři čtvrtiny námi zachycených přestupů tedy mohou být dány problémy žáka ve škole, logistickými důvody (dojíždění) apod. Nemůžeme však vyloučit, že rezidenční mobilita může být vyšší, avšak změna pobytu není škole ohlášena. Tyto výsledky mají několik důležitých omezení. Jak bylo 
Tab. 5. Hlavní události ve vzdělávací dráze tří vybraných žáků ve sledovaném období

\begin{tabular}{|c|c|c|c|c|c|c|c|c|c|c|c|c|}
\hline 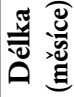 & $\stackrel{ }{\forall}$ & nి & $\stackrel{ }{\forall}$ & ก) & nి & in & 아 & in & in & ก) & 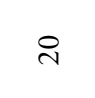 & in \\
\hline $\begin{array}{l}\overrightarrow{3} \\
0 \\
0 \\
0 \\
0\end{array}$ & 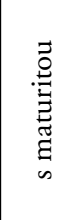 & 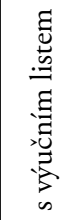 & 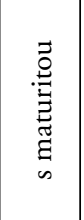 & 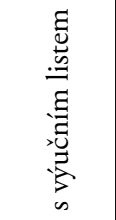 & 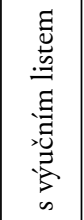 & 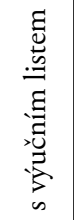 & 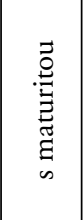 & 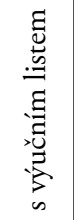 & 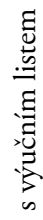 & 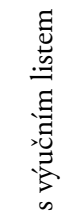 & 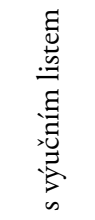 & 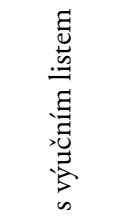 \\
\hline$\frac{\ddot{0}}{0}$ & 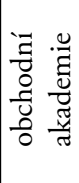 & 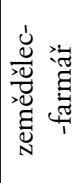 & 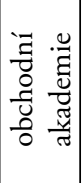 & 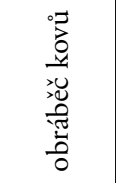 & 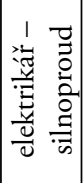 & 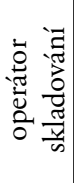 & 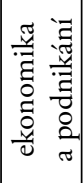 & 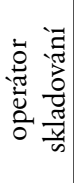 & 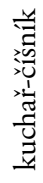 & 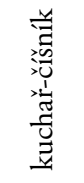 & 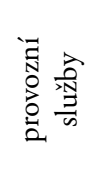 & 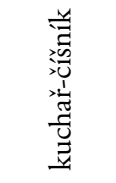 \\
\hline $\begin{array}{l}3 \\
0 \\
0 \\
0 \\
0\end{array}$ & 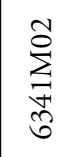 & $\begin{array}{l}\varpi \\
o \\
\text { I } \\
\\
\forall\end{array}$ & 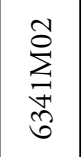 & 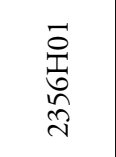 & 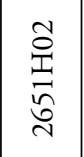 & 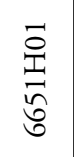 & 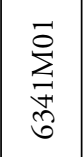 & 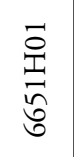 & $\begin{array}{l}\bar{\sigma} \\
\text { I } \\
\tilde{n} \\
\tilde{\sigma}\end{array}$ & $\begin{array}{l}\overline{0} \\
\text { I } \\
\text { ñ } \\
6\end{array}$ & \begin{tabular}{l}
$\vec{\sigma}$ \\
†ิ \\
\multirow{7}{*}{} \\
$\hat{\sigma}$
\end{tabular} & 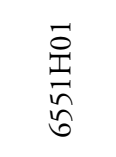 \\
\hline 突 & $\begin{array}{l}\stackrel{0}{0} \\
\stackrel{\sim}{1} \\
\ddot{0} \\
\dot{\infty}\end{array}$ & 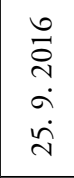 & 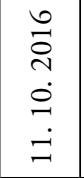 & 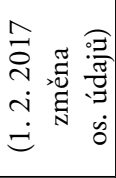 & $\begin{array}{l}0 \\
\stackrel{0}{0} \\
\dot{0} \\
\dot{0}\end{array}$ & 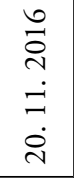 & 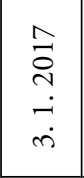 & & $\begin{array}{l}\stackrel{0}{0} \\
\stackrel{\sim}{2} \\
\stackrel{2}{\circ}\end{array}$ & $\begin{array}{l}\mathfrak{0} \\
\tilde{\sigma} \\
\dot{0} \\
\infty \\
\infty\end{array}$ & $\begin{array}{l}\stackrel{ }{\circ} \\
\stackrel{\sim}{1} \\
\dot{\sim}\end{array}$ & 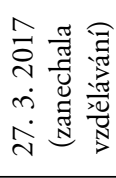 \\
\hline 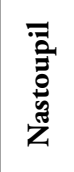 & $\begin{array}{l}0 \\
\stackrel{0}{0} \\
\dot{\imath} \\
\dot{\imath}\end{array}$ & $\begin{array}{l}\stackrel{0}{0} \\
\stackrel{0}{0} \\
\dot{a} \\
\dot{a}\end{array}$ & 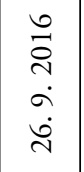 & $\begin{array}{l}\stackrel{0}{0} \\
\stackrel{0}{1} \\
\dot{0} \\
\stackrel{1}{J}\end{array}$ & 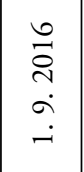 & $\begin{array}{l}\stackrel{0}{0} \\
\stackrel{0}{0} \\
\dot{0} \\
\dot{\Xi}\end{array}$ & 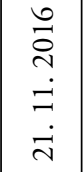 & 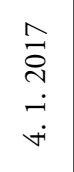 & 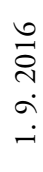 & $\begin{array}{l}\stackrel{0}{0} \\
\stackrel{\circ}{\circ} \\
\dot{\sim} \\
\dot{\sim}\end{array}$ & $\begin{array}{l}\stackrel{0}{0} \\
\stackrel{\sim}{\sim} \\
\dot{a} \\
\dot{a}\end{array}$ & $\begin{array}{l}\text { 롱 } \\
\text { ָे } \\
\dot{\sim}\end{array}$ \\
\hline$\frac{\pi}{3}$ & 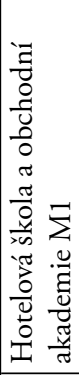 & 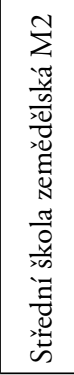 & 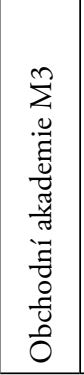 & 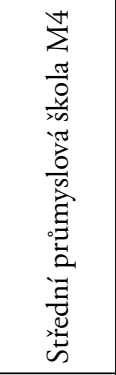 & 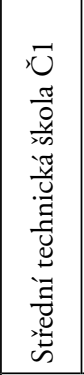 & 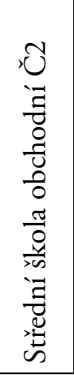 & 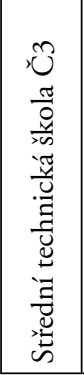 & 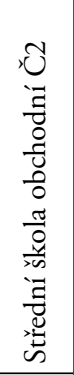 & $\begin{array}{l}5 \\
\frac{\pi}{0} \\
0 \\
\frac{8}{20} \\
-\frac{0}{3} \\
0 \\
\frac{0}{0} \\
0 \\
0 \\
0\end{array}$ & 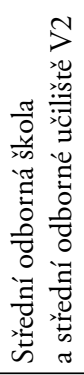 & 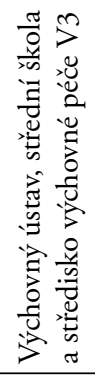 & 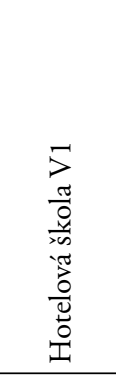 \\
\hline & \multicolumn{4}{|c|}{ 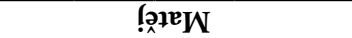 } & \multicolumn{4}{|c|}{ ершәว } & \multicolumn{4}{|c|}{ еҮIJI } \\
\hline
\end{tabular}


uvedeno, kvantitativně jsme analyzovali jen nejjednodušší události, kdy žák přestoupil právě jednou na jinou školu. To znamená, že nejsou zahrnuty pravděpodobně hojné př́ípady, kdy žák změnil typ studia, ale zůstal ve stejné škole, nebot řada velkých odborných škol nabízí současně různé typy studia (maturitní i nematuritní). Za upozornění na tuto skutečnost děkujeme recenzentovi, stejně jako za doporučení zaměřit se na problematiku přestupů do učňovských oborů motivovaných neúspěšností $\mathrm{v}$ jednotné části maturitní zkoušky nebo obavami z ní. $S$ tím souvisí další limit dat, která pokrývají jen přestupy uvnitř školního roku, přibližně v období prvních tří čtvrtletí. Přestupy po uzavření celého ročníku (probíhající o hlavních prázdninách) mohou mít odlišnou strukturu. Naše rozhodnutí použít v daném okamžiku nejaktuálnější data (z jarního sběru) se zpětně jeví jako omezující, data z podzimního sběru zahrnují i letní prázdniny a jsou vhodnějším kandidátem na budoucí analýzy. Konečně analýza složitějších př́padů (řetězených přestupů podobných těm, které jsme uvedli v části 3.2) si vyžádá bud' časově náročné ruční interpretování dat podobné postupu v části 3.2, anebo vývoj složitějších softwarových prostředků.

Zatímco právě uvedená omezení jsou v principu překonatelná a představují možný další krok výzkumu, $v$ tuto chvíli nepřekonatelným limitem zvoleného výzkumného př́stupu (použitých dat) je nemožnost provést analýzy, které by šly za deskripci a analyzovaly vztah pozorovaného jevu $\mathrm{k}$ dalším kontextovým proměnným na úrovni žáka.
To se ukazuje zvlášt naléhavé ve světle velkých regionálních rozdílů $\mathrm{v}$ míre non-rezidenčních přsestupů (obr. 1). Naše nálezy zde odpovídají zahraničním zkušenostem, podle nichž jsou transfery výrazně častější u rizikových skupin žáků (Welsh, 2017; Cordes et al., 2016). Kumulace různých sociálních i edukačních problémů v Ústeckém a Karlovarském kraji je doložena řadou zjištění, $\mathrm{v}$ neposlední řadě víme $\mathrm{z}$ výběrových šetření, že zde mají žáci nejnižší průměrný socioekonomický status a také výsledky žáků se ukazují v různých mezinárodních i národních šetřeních nejnižší (např. Blažek \& Př́hodová, 2016; Suchomel, 2017). Vysoká míra meziškolní mobility je tak dalším kamínkem do mozaiky dokreslující situaci $\mathrm{v}$ těchto regionech.

\subsection{Metodologické poznámky}

Výhodou administrativních dat je nízká cena jejich pořízení. Nevýhodou je, že většinou nemůžeme ovlivnit údaje, které jsou sbírány. Abychom mohli provádět interpretace, je proto klíčové propojovat údaje $\mathrm{z}$ různých administrativních databází. Tady narážíme na řadu - v tuto chvíli pro nás ještě nepřekonatelných - překážek. Zásadní je legislativa. $V$ principu existují mikrodata (např́klad některé údaje o rodině dítěte sbírané při porodu), která by prostřednictvím vhodného identifikátoru šlo propojit s údaji o vzdělávací kariéré žáka. $V$ praxi však nedovoluje legislativa tato data na úrovni jedince použít, a tím přicházíme o možnost provést sofistikovanějšś analýzu.

Způsob anonymizace matrikových dat nám neumožnil ani propojit údaje o jedin- 
ci $\mathrm{z}$ více různých sběrů $\mathrm{v}$ rámci jedné databáze. Nemůžeme se tak podívat, jak se dále vyvíjela vzdělávací dráha Matěje a Čendy, nebo zda se Věrka později vrátila do školy (tím spíše zda a kde našla zaměstnání apod.). Doufáme, že se v budoucnu podaří - např. zavedením ireverzibilního bezvýznamového identifikátoru (hash code) trvale přiděleného žákovi - rozšriřit možnosti takovýchto analýz. Se zřetelem $\mathrm{k}$ našemu okruhu výzkumných zájmů, do nějž patří na předním místě vztah přestupů $\mathrm{k}$ předčasným odchodům, je potenciálně možné $s$ existujícími daty provést retrospektivní analýzu vzdělávací dráhy všech žáků středních škol, kteři předčasně odešli ze vzdělávání. Vyžadovalo by to ale bud' uvolnění celého anonymizovaného matrikového souboru (ten samozřejmě nemáme $\mathrm{k}$ dispozici), nebo jiné zadání pro export dat, anebo zpř́stupnění dat formou bezpečného datového centra. $\mathrm{Na}$ druhou stranu je pravda, že již současným způsobem zpř́istupněná data umožňují i další analýzy, které jsme dosud neprovedli - např. propojením $s$ geografickými informačními systémy sledovat, zda při přestupech žáci směřují spíše blíže $\mathrm{k}$ obci trvalého pobytu (jako tomu bylo u Matěje), tedy zda při změně školy hrají roli logistické důvody.

Při práci s administrativními daty na sebe naráží potřeba monitorovat systém a potřeba chránit osobní data. Rostoucími požadavky na zpř́stupňování dat může být ministerstvo školství zahlceno. Systémovým řešením by mohlo být např. vytvoření „bezpečného“ pracoviště (safe room), kde by za př́sně definovaných podmínek mohli výzkumníci pracovat $s$ mikrodaty z různých rezortů.

\section{ZÁVĚR}

Předložený výzkum má pouze pilotní charakter. Přesto data přinesla některá zajímavá zjištění, která však vyžadují další ověření a hlubší interpretaci. Jedním z našich hlavních cílů bylo ukázat možnosti a problémy při využití administrativních dat pro analýzu různých aspektů přestupů mezi středními školami. Potenciál těchto dat se potvrdil, avšak projevily se také limity, na které jsme poukázali v diskusi. Jako klíčové se nám zdá posílení kapacity př́islušných úřadů tak, aby se usnadnila cesta výzkumníků $\mathrm{k}$ administrativním datům a jejich kvalita. Prospěch z toho bude mít jak školství, tak české společenské vědy.

Po věcné stránce se prokázalo, že přestupy mezi středními školami a typy studia se kumulují do prvního ročníku, a ukazují tak na snahu korigovat výběr školy. Naprostá většina změn nevede přes pomyslnou hranici mezi maturitními a nematuritními obory. Zejména prestupy $\mathrm{z}$ učňovských do maturitních oborů jsou jen velmi malou částí mobility. Data ukazují, že celková mobilita je nejvyšší v obou regionech severozápadních Čech a že pravděpodobně souvisí s jinými pedagogicky a sociálně rizikovými jevy.

\section{PoděKování}

Děkujeme pracovnikuim odboru školské statistiky, analýz a informačni strategie $M \check{S} M T \check{C} R$, kteři nám poskytli administrativni data. Děkujeme rovněž recenzentům za velmi užitečné pripominky $k$ textu. 


\section{LITERATURA}

Backes, S., \& Hadjar, A. (2017). Educational trajectories through secondary education in Luxembourg: How does permeability affect educational inequalities? Revue Suisse des Sciences de l'Education, 39(3), 437-460.

Bereményi, B. Á., \& Carrasco, S. (2018). Caught in the triangle of mobility: social, residential and pupil mobility. British Journal of Sociology of Education, 39(1), 32-46.

Blažek, R., \& Př́ihodová, S. (2016). Mezinárodni šetřeni PISA 2015: Národni zpráva - prírodovédná gramotnost. Praha: ČŠI.

CEDEFOP. (2012). Permeable education and training systems: reducing barriers and increasing opportunity. Briefing Note No. 9072. Thessaloniki: CEDEFOP.

Cordes, S. A., Schwartz, A. E., Stiefel, L., \& Zabel, J. (2016). Is neighbourhood destiny? Exploring the link between neighbourhood mobility and student outcomes. Urban Studies, 53(2), 400-417.

Demie, F., Lewis, K., \& Taplin, A. (2005). Pupil mobility in schools and implications for raising achievement. Educational Studies, 31(2), 131-147.

Dobson, J. (2008). Pupil mobility, choice and the secondary school market: assumptions and realities. Educational Review, 60(3), 299-314.

Dvořák, D., \& Straková, J. (2016). Konkurence mezi školami a výsledky žáků v České republice: pohled zblízka na šetření PISA 2012. Pedagogika, 66(2), 206-229.

Elder, G. H., Jr. (1996). Human lives in changing societies: Life course and developmental insights. In R. B. Cairns, G. H. Elder, Jr., \& E. Jane Costello (Eds.), Developmental science (s. 31-62). New York: Cambridge University Press.

Finn, J. D. (1993). School engagement \& students at risk. Washington: U.S. Dept. of Education, Office of Educational Research and Improvement, National Center for Education Statistics.

Friedman, M., \& Friedman, R. (1990). Free to choose: A personal statement. San Diego: Houghton Mifflin Harcourt.

Gasper, J., DeLuca, S., \& Estacion, A. (2012). Switching schools: Revisiting the relationship between school mobility and high school dropout. American Educational Research Journal, 49(3), 487-519.

Gibbons, S., \& Telhaj, S. (2011). Pupil mobility and school disruption. Journal of Public Economics, 95(9-10), 1156-1167.

Hattie, J. (2009). Visible learning. London: Routledge.

Hendl, J. (2012). Přehled statistických metod zpracováni dat. Analýza a metaanalýza dat. Praha: Portál. Hendl, J., \& Remr, J. (2017). Metody výzkumu a evaluace. Praha: Portál.

Hlad’o, P. (2010a). Dynamika rozhodování žáků základních škol o další vzdělávací dráze. Studia paedagogica, 15(2), 87-104.

Hlad’o, P. (2010b). Vliv sociálního okolí na kariérové rozhodování žáků při přechodu do vyššího sekundárního vzdělávání. Pedagogická orientace, 20(3), 66-81. 
Hlad’o, P., \& Drahoňovská, P. (2012). Rozhodováni žáků základnich a středních škol $o$ dalšim studiu a práci v pohledu žákủ i jejich rodiču. Praha: Národní ústav pro vzdělávání.

Hlad’o, P., \& Šlapalová, K. (2018). Di̊vody žákư střednich škol pro opakovaný prestup na jinou školu. Výzkumná zpráva pro Jihomoravský kraj. Brno: FF MU.

Jacob, M., \& Tieben, N. (2009). Social selectivity of track mobility in secondary schools. European Societies, 11(5), 747-773.

Kerbow, D. (1996). Patterns of urban student mobility and local school reform. Journal of Education for Students Placed at Risk, 1(2), 147-169.

Kertesi, G., \& Kézdi, G. (2011). The Roma/non-Roma test score gap in Hungary. American Economic Review, 101(3), 519-525.

Kubáň, M. (2016). Otevřená data v České republice a v zahraničí. Předneseno na Semináři ÚV ČR. Dostupné z https://opendata.gov.cz.

Mehana, M., \& Reynolds, A. J. (2004). School mobility and achievement: a meta-analysis. Children and Youth Services Review, 26(1), 93-119.

Millová, K. (2009). Analýza některých současných teorií celoživotního vývoje. E-psychologie, $3(4), 45-54$.

Oates, T. (2017). A Cambridge approach to improving education. Using international insights to manage complexity. Cambridge: Cambridge Assessment.

OECD. (2016). Research ethics and new forms of data for social and economic research. OECD Science, Technology and Industry Policy Papers, No. 34. Paris: OECD Publishing.

Poupeau, F., François, J.-Ch., \& Elodie, C. (2007). Making the right move: how families are using transfers to adapt to socio-spatial differentiation of schools in the greater Paris region. Journal of Education Policy, 22(1), 31-47.

Rumberger, R. W. (2003). The causes and consequences of student mobility. Journal of Negro Education, 72(1), 6-21.

Rumberger, R. W., \& Larson, K. A. (1998). Student mobility and the increased risk of high school dropout. American Journal of Education, 107(1), 1-35.

Scharle, Á. (2018). The legal and technical solutions for administrative data access in Hungary. Vystoupení na semináři Hidden treasure for policy research: Administrative micro data. CERGE-EI, Praha.

Srholec, M. (2016). Metodika hodnoceni hospodárnosti účelové podpory pro aplikovaný výzkum a vývoj ve firmách. (Online). Dostupné $\mathrm{z}$ https://idea.cerge-ei.cz.

Suchomel, P. (2017). Hlavní závěry z výběrového zjištování výsledků žáků 5. a 9. ročníků ZŠ ve školním roce 2016/2017. Informačni bulletin ČŠI. (Online). Dostupné z www.csicr.cz.

Trhlíková, J. (2012). Predčasné odchody ze vzdèláváni na stredních školách. Kvalitativni analýza rozhovorù s experty a príklady dobrých praxí. Praha: Národní ústav pro vzdělávání.

Vyhnálek, J. (2016). Meziškolní mobilita: přehledová studie výzkumných témat. Orbis Scholae, 10(1), 63-96. 
Welsh, R. O. (2017). School hopscotch: A comprehensive review of K-12 student mobility in the United States. Review of Educational Research, 87(3), 475-511.

RNDr. Dominik Dvoráa, Ph.D.

Univerzita Karlova, Pedagogická fakulta, Ústav výzkumu a rozvoje vzdělávání;

e-mail:dominik.dvorak@pedf.cuni.cz

PsLic. Jan Vyhnálek

e-mail:vyhnalekj@gmail.com

DVOǨ́A, D., VYHNÁLEK, J. Inter-School Mobility of Pupils of Middle Schools in the Czech Republic

We present pilot data on moves by Czech pupils between middle schools. It is based on administrative microdata - the spring collection of information on the school register in 2017. We analysed 4,533 cases of moves. We illustrate the aggregated data using three cases of chain moves. The results show that $11.5 \%$ of moves were from a "maturita" programme to a "non-maturita" discipline, and only 3.2\% were in the opposite direction. The other moves did not involve a change in type of studies. The number of changes of school without change in family place of permanent address varied strikingly between regions. Inter-school mobility could be an important indicator drawing attention to risk pupils and schools. The methodology of the analysis of administrative data has considerable potential but the current system of the collection and administration of data in the Czech school system lags behind the advanced countries.

Keywords: inter-school mobility, secondary school, administrative data. 